\title{
PACIFISM AND THE MILITARY - A PERSPECTIVE
}

Cpl J.B. Bloom*

\section{Introduction}

Anti-war feeling is perhaps as old as warfare itself. There are, for example, ancient Chinese and Persian poems that are powerful expressions of pacifism. The pacifist phenomenon is thus nothing new, and it is indeed understandable that as a reaction against the undoubted horrors of war there should be some in every age who would be inclined to reject it entirely. Others would seek only that when war is waged it is justifiable and as limited in its ill-effects as possible. For still others, however, war and conquest is an end in itself, the glory and heroism of victory and battle holding out the promise of an inspiring vision. These three positions are, of course, overdrawn. Nevertheless, it is the tensions between these three types of perspective, including here the complexities of intermediate and overlapping positions, that determine the background and provide the dynamic for confrontation between pacifism and the military.

The modern world is presently witness to what seems to be an increasingly vigorous and influential outpouring of pacifist sentiments, as embodied particularly in mushrooming "peace movements" most active in the countries of the Free World but conspicuously absent in any but the smallest degree in those countries locked firmly into the Communist orbit. All this comes less than a decade after the tumultuous protests against the Vietnam war, but the target this time round is that of nuclear weapons particularly, it seems, if they are on the side of the West. It is not surprising, therefore, that many observers see in this revival of pacifist influence a threat to Western military efforts to effectively counter Soviet and Communist military power and expansionist opportunism. In this view, the form which contemporary pacifism has taken can be seen as part of a spreading malaise throughout the Western World which is contributing to a possibly disastrous paralysis of Western political and military will in the face not only of nuclear threats but also against the scourge of international terrorism and many lesser conflicts around the globe.

A particularly distressing element in the above picture is the manner and the sheer scale in which naive but otherwise worthy pacifist sentiments and idealistic intentions have been so successfully manipulated by opportunistic Communist and leftist influences. The question arises, then, as to whether it is possible or indeed useful to separate and distinguish the present-day pacifist phenomenon with what is possibly a genuine humanitarian ethical impulse that undergirds a principled pacifism unable to come to terms with and formed as a reaction to the perceived inhumanity and destructiveness of warfare. To put it more bluntly, is there any merit whatsoever in the pacifist position, anything that will in fact contribute in the real, imperfect world to that which the pacifist proclaims to be his ideal, namely peace, but hopefully not at any price?

To be sure, this is not to say that there are not very many varieties of modern pacifism, or that the dividing line between pacifist and non-pacifist may sometimes be extremely difficult to draw. The pacifist issue is a multifaceted and complex one, and it defies any simple categorisation. A full and accurate understanding therefore implies coming to terms with this complexity in as comprehensive a manner as possible. This article will focus firstly on a definition of pacifism, then its historical background and incidence in the twentieth century will be dealt with especially with respect to the pattern of conscientious objection in the two world wars. This will be followed by a consideration of military difficulties and relevant issues relating to the conscientious objector. A comment will then be passed on the modern "peace movements" leading on to an examination of the issues raised by the pacifist response to the moral dilemma of war. Pacifism is critiqued from both a moral and a practical standpoint, raising considerations here of its real moral and ethical significance, the question of religion, the relationship of the military to society, and the ethics of war.

\section{A Definition of Pacifism}

Since it is generally true that pacifism has been more often ridiculed and condemned than understood, there is a need to attempt a defi- 
nition of it and to draw a few distinctions within it. As Paskins and Dockrill point out, one difficulty arises in distinguishing what sets pacifism apart from a mere preference for peace as against war. Furthermore, it seems that no useful purpose is served by trying to delimit the range of beliefs that make someone a pacifist: the diversity of view is too great. The most sensible definition, then, is in terms of a link between beliefs and actions. A person is thus a pacifist if and only if he has beliefs such that, if he acted in the way those beliefs require, he would refuse all participation in war' ${ }^{1}$.

As Paskins and Dockrill note, this formulation does not require that all pacifists act as their beliefs require - fear, cowardice or intimidation may compel a pacifist to eschew the logically consistent role of conscientious objector to military service. The definition is also fully accommodative of the great varieties to be found within pacifism. It includes, for instance, the position of the Jehovah's Witness, who is a pacifist not because of any beliefs he has about violence or war as such, but because he believes God to have forbidden him to serve in the kingdoms of this world. While he is quite prepared to fight at Armageddon (a battle not however conceived of in normal military terms) and has no special objection to war or violence, the implications of his beliefs for what he should do plainly makes him a pacifist. $^{2}$

The difficulty remains, however, of distinguishing between different types of pacifism. A religious pacifism, for example, may have much overlap and in part draw inspiration from a pacifism based "purely" on political, moral or ethical grounds. The definition provided by Paskins and Dockrill does not in itself give grounds for distinguishing between a selective and a universal objection to war, nor does it indicate to what degree a pacifist would willingly compromise by way of perhaps accepting non-combatant or civilian alternative service. Some writers, such as Peter Brock, also see pacifism in more positive terms as combining advocacy of personal nonparticipation in war with an endeavour to find non-violent means of resolving conflict. ${ }^{3}$ Within the pacifist community itself there exists a wide spectrum of opinion on the subject of war, as well as on other political, religious and moral problems. Pacifist ideals range from rigid vegetarianism, which recoils from killing any sentient being, to a conscientious objection which is confined to fighting in national wars and does not include taking human life in self-defence or in defence of an accepted system of international law.

\section{Elements of Twentieth-century Pacifism}

Peter Brock argues that pacifism emerged as a significant political factor only after the outbreak of the First World War ${ }^{4}$ This development, however, was restricted mainly to Great Britain and the United States. Four pre-twentieth century sources of particular importance are singled out by Brock as contributing to this post-1914 pacifism, namely:

- the otherwordly doctrine of suffering non-resistance as developed by the Anabaptists and Mennonites of the Reformation era;

- the peace testimony dating back to the Commonwealth period in English history of the Quakers, who were to contribute substantially to the creation of an organised Anglo-American peace movement in the nineteenth century;

- the institutional approach to the problem of war evolved by these peace societies; and

- the socialist anti-militarism which emerged, along with the organised labour movement, in the half-century before 1914. At its best, this expressed an ideal of human brotherhood which trancended frontiers and united races.

Whereas compulsory military service had long acted as a deterrent to the growth of pacifism on the European continent, its introduction in Great Britain and the United States during World War I served instead to reactivate pacifism in the differing political environment of these two countries. Conscription here, in fact, was to become the "harsh midwife of twentieth-century pacifism." 5

Following the signing of armistice in 1918, popular disillusionment with the horrors and seeming futility of the past war meant a far wider potentially sympathetic audience for the spreading of pacifist ideals than ever before. Nevertheless, outside the Anglo-American countries, it was only in India that pacifism was to find significant root in the form of Gandian techniques of passive resistance. Various peace societies operated during this period, often giving some assent to the ideas of the left and sometimes requiring of their members a "peace pledge" renouncing any personal participation in any future war. The pacifist movement, however, was to lose much of its political relevance with the departure from its ranks of many, including the leftwing activists, 
who were to reconsider their stand following the rise of Hitler to power and the Spanish Civil War. With the outbreak of war in 1939, the pacifist movement was to contract once more within the confines of a quasi-religious sect. ${ }^{6}$.

Post-World War II pacifism continued to suffer from declining vigour. A rebirth was to occur only in the second half of the fifties, and this was strongly related to increased public fears of the threat presented by nuclear war. Mass protest rallies sought to influence government and public opinion in the direction of nuclear disarmament, even unilaterally, in a campaign summed up in the slogan "Ban the Bomb". In America, anti-war feelings were stirred by the war in Vietnam, and conscientious objection to conscription was again to become an issue. Many of those who opposed the Vietnam war were, however, political inspired selective pacifists with no objection to violence or war as such. American withdrawal from Vietnam thus meant a severe loss of support for the anti-war pacifist movement, although a sort of "nuclear pacifism" widespread amongst the general public remained an issue on which support could be galvanised. Of the utmost concern to the military in Western countries, however, is the evidence increasingly coming to light of how successful has been the Communist penetration and manipulation of the modern "peace movements", at present most active in Britain and Western Europe.

In retrospect, it is perhaps true to say that the greatest test of pacifist-military relations was to be found during the two world wars. The pattern of conscientious objection in these two wars will thus now be examined, leading on to an assessment of various issues and problem areas in the relationship between society, the military and the conscientious objector

\section{Conscientious Objection in World Wars I and II}

Official provision for conscientious objection to military service in both world wars was to be found almost exclusively in the English-speaking countries of the world. Perhaps the most significant thing to note is that in countries such as Great Britain and the United States the actual number of objectors applying for military exemption represented a very small percentage of the total number drafted for military service. Out of roughly eight million enrolled in World War II Britain, about 60000 or .8 percent applied for registration as conscientious objectors. ${ }^{7}$ In the United States, an approximate estimate of the total number of objectors is 100000 i.e. 3 per-

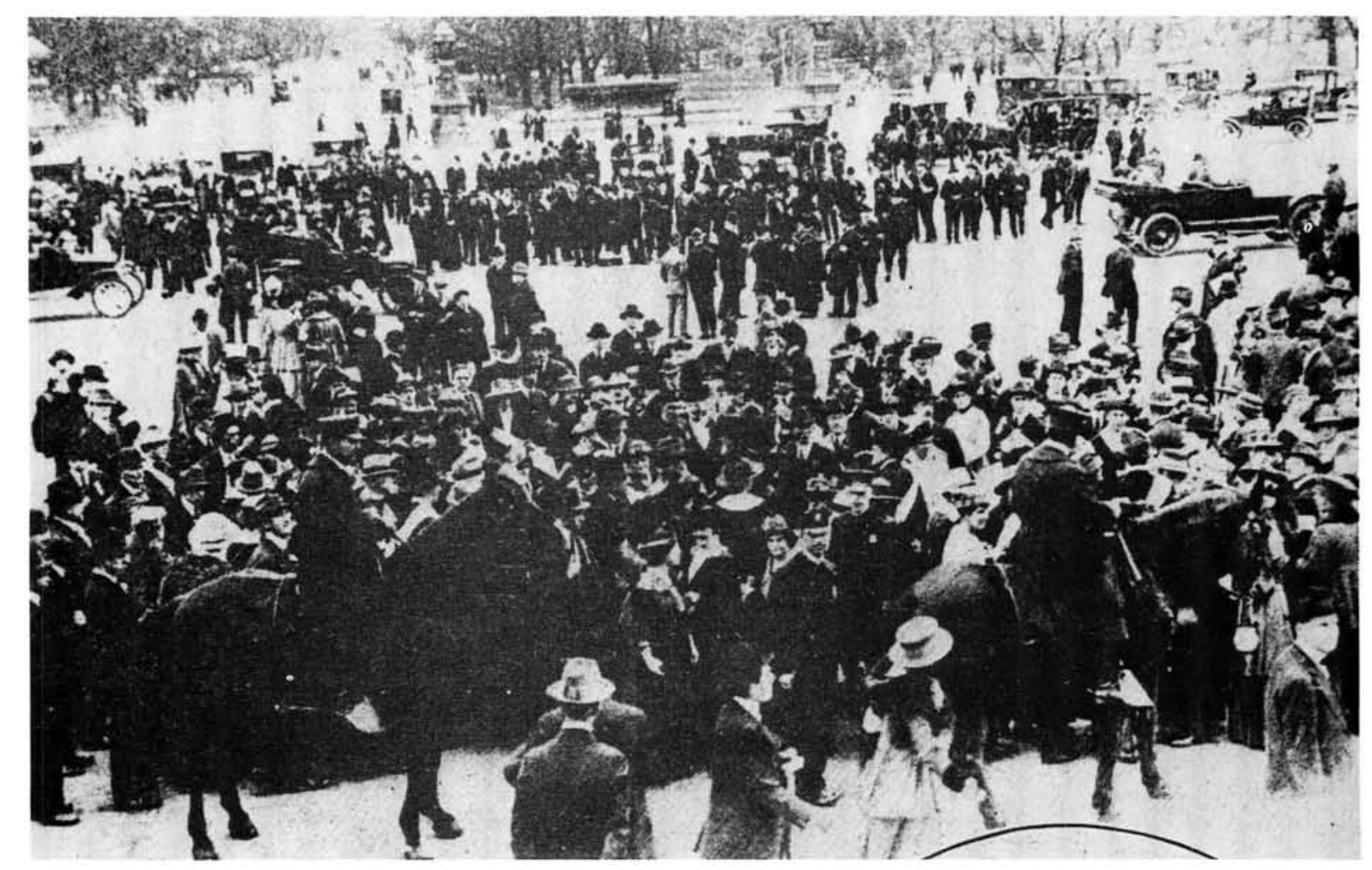

An early paciflst demonstration - Washington, circa 1916. 


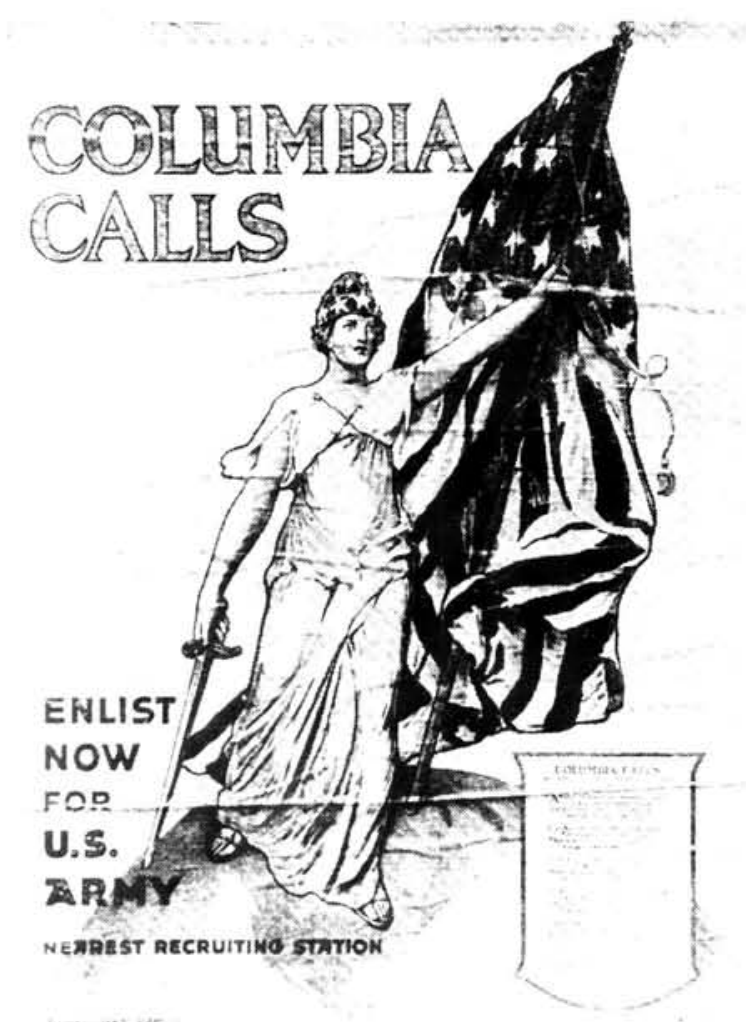

An American World War I enllstment poster.

cent of 34 million registrants for military service. ${ }^{8}$ The mere question of numbers, however, does not corivey the difficulties experienced in trying to accommodate these objectors in a useful and practical manner as well as minimizing any possible negative impact they might have on the war effort.

Objectors in both wars were divided between "alternativists" who were prepared to accept some form of alternative service, either civilian or non-combatant, and "absolutists" who held out for unconditional exemption. ${ }^{9}$ The latter, who were especially problematic in World War I Britain, felt that to accept any alternative to military service was to become an accomplice in the war conscription system, which demanded that a man sacrifice his life even in a cause in which he did not believe. Like the old-time Quakers they denied that a government had the right to ask from one of its citizens any service in exchange for doing what he thought was right.

While no less opposed than the absolutists to the principle of military conscription, the alternativists felt nevertheless that in times of national emergency, such as war, the state had a right to demand some kind of service from its citizens. Alternative service was regarded not as unwilling tribute exacted by the state but rather as a means whereby they could witness to their pacifist convictions. Whereas the absolutists were out primarily to smash the conscription system, they wanted rather to prove that anti-militarism was consistent with good citizenship and that pacifists were prepared to help their country in any way that they conscientiously could.

\section{The British Experience}

The most liberal of legislative provision for conscientious objectors was to be found in Britain. In both world wars the objector could either be granted unconditional exemption, or exemption on condition that he undertook non-combatant service in the armed forces or engaged in work considered to be of national importance. A special Non-Combatant Corps was in fact set up, forming part of the regular army. Although the legislation did not specify either that the conscientious objection be based on religious belief or that it be applicable to all wars, the overall spirit in which it was interpreted came to be a crucial factor in determining, for instance, whether sincere alternativists or non-religious objectors were not to have their cases dismissed and themselves lumped in army camps or prison together with the more refractory absolutists. ${ }^{10}$

In general, the British tribunals in World War II were better staffed, more informed and fairer than those of World War I. After the latter war, the War Office in fact conceded that tribunals had "rejected the applications of hundreds ... whose consciences were sincere, and to protect whom the conscience clause was expressly framed by the House of Commons."11 The conditions of alternative civilian service were furthermore of a semi-penal character, such that one writer commented that it "proved to a discreditable shambles. It never came within measuring distance of giving conscientious objectors the work of national importance they were promised. It insisted on punishing men officially declared to be genuine in their conscientious objection. Above all, it went a long way towards justifying its rejection by the absolutists as a diversionary fraud - and towards increasing their numbers." 12

Despite the fairer administration of the British tribunal system in World War II, problems were still experienced in the attempt to accurately assess conscience. Younger objectors especially were at a distinct disadvantage in that they could not always produce hard supporting evidence such as witnesses, letters of recommen- 
dation, or a past record of pacifist activity. Many tribunal members also experienced difficulty in understanding why most pacifists objected to non-combatant service. The view of most objectors was that the basic aim of such service was still the prosecution of war and not the saving of human life. Much trouble would have been saved if tribunals had recognised that many of those whose objection to combatant service they had acknowledged to be sincere, also had genuine scruples concerning service in the NonCombatant Corps or Royal Army Medical Corps. Indeed, of those objectors whose clash with the law led to prison sentences, it was mostly the case that their conscientious scruples had not been adequately dealt with at their tribunal hear${\text { ings. }{ }^{13}}^{13}$

The number of claims accepted by the local and appellate tribunals was approximately 80 percent, with roughly 6 percent granted unconditional exemption, 49 percent conditional exemption, and 25 percent non-combatant service. ${ }^{14}$ As compared to the First World War, the straight political objector as well as the absolutist was no longer an important factor in the pattern of conscientious objection. The impulse for the overwhelming number of objectors was that of religious or religio-ethical motivation, but Appellate Tribunals were even prepared to accept the validity of non-pacifist objection if convinced of the sincerity of the applicant. ${ }^{15}$ The civilian alternative service most favoured by tribunals was that of agricultural work or forestry, followed closely by hospital work, civil defence and coal mining. ${ }^{16}$

\section{The American Experience}

An interesting contrast is provided by the experience of the United States. In World War I, legal exemption was provided only to members of the historic peace churches, such as Quakers and Mennonites. In practice, however, the administration was forced to extend the categories of those entitled to exemption and to furlough men unwilling to accept non-combatant service for work in agriculture. This experience was embodied in the 1940 conscription bill which provided exemption for those "who, by reason of religious training and belief, are conscientiously opposed to participation in war in any form." For those exempted from non-combatant as well as combatant service, work of national importance under civilian direction was to be provided. The task of deciding this fell not to specially constituted tribunals but to the local (Selective Service) draft boards. Unlike in Britain, no provision was made for unconditional exemption for the absolutist, while the sincere non-religious objector, even when he was a complete pacifist, was at least on paper left with no alternative except to submit or go to prison. ${ }^{17}$

The purely "humanitarian objectors" posed a special problem. Their objection did not stem from any religious training or belief, yet they apposed all war as contrary to ethical code, claiming a sanction for their stand as absolute as that of the religious objector. While the letter of the law meant an automatic rejection, it was also possible to stretch its meaning a little by identifying an ethical code with a religious belief. Indeed, an appeal court was to claim that "a conscientious objection to participation in war under any circumstances may justly be regarded as a response of the individual mentor, call it conscience or God, that is for many persons at the present time the equivalent of what has always been thought a religious impulse."18

In regard to selective objectors, the local boards most often rejected their applications, especially if these men were professedly antireligious socialists or anarchists who refused to fight in "imperialist wars." There were, however, borderline groups where a decision was extremely difficult. Thus, while the objections to fighting of the Jehovah's Witnesses were incontestably the result of religious training and belief, they could be ineligible for exemption since their refusal to participate in war was not absolute. Impressed by the patent sincerity of most Witnesses and their devotion to their church, some boards gave them exemption in one form or another, while others dismissed their applications. Another group whose unwillingness to fight straddled the borderline between pacifist and selective objection was found among Roman Catholic opponents of war. The problem here lay with those Catholic objectors who without claiming to be unconditionally pacifist, refused to fight in modern wars because they considered the conditions under which such wars would be waged as inevitably contravening traditional Catholic teaching concerning a just war. ${ }^{19}$

Of considerable interest in America at this time was the operation of alternative civilian service run initially at least by the three historic peace churches. Assignees to Civilian Public Service (CPS) served without pay in a church and later government-organised work camp. Most projects centred on agricultural and conservation work, but CPS men served also in hospitals, 
state training schools, university laboratories, mental asylums etc. Much useful work was indeed done both in camp and in special project work, but a cogent criticism was that much CPS work "was unworthy either of the calibre of men and convictions placed at its disposal or of the sacrifices of freedom and security which were imposed." Specialist skills were often ignored while much of the labour seemed to be just "made" work or lacking in any special urgency or importance that would fit the definition of "national importance". ${ }^{20}$ CPS director General Hershey's view was that some sacrifice of efficiency was often necessitated if Congress and the public were to be convinced that their sacrifice was commensurate with avoiding military service. $^{21}$ Discontent in the camps, however, was sometimes severe enough as to lead to work strikes and riots.

In the minds of critics, CPS was merely a means by which the government could conveniently silence opposition and relieve the military establishment of a problem. Both government and pacifists were later to admit that mistakes had been made on both sides. Looked at in pragmatic terms, the 11868 men in CPS produced some 8 million man-days of labour which cost the government a modest $\$ 4731000$ as opposed to the over $\$ 18000000$ it would have had to pay at army rates. General Hershey himself, however, was unsatisfied with such a pragmatic evaluation, feeling that CPS actually made a contribution to the strength of the nation. CPS was seen as a symbol of "the degree of accommodation of divergent views which is attainable under this country's democratic form of government," affirming the basic principles of American culture, primarily the concept of tolerance and the supremacy of conscience over the state. ${ }^{22}$

\section{Conscientious Objection in other Countries}

In none of the three British dominions where conscription was introduced - Australia, New Zealand and Canada - was there any provision for unconditional exemption. Religious grounds for exemption was specifically legislated for, but non-religious claims, if based on pacifist grounds, were often recognised in practice, if not always in law. In addition, government-run schemes of civilian alternative service were instituted in Canada and New Zealand. ${ }^{23}$

In stark contrast to this sort of tolerance were conditions in Germany and Soviet Russia, where the pacifist movement had been ruthlessly sup- pressed long before the outbreak of war. Conscientious objection to war scarcely existed in war-time Germany, but for at least eight couragous objectors to military service in Hitler's armies, refusal meant execution. Small pacifist groups in German-occupied Denmark, Holland and Norway did, however, still operate to some extent, mainly participating in the largely nonviolent resistance of the civil population against attempts to nazify cultural life. Taking an overall assessment of pacifism in World War II, Brock's conclusion is that whether driven underground in Nazi-occupied Europe, or able to function openly as in Great Britain and the Commonwealth or in the United States and certain neutral countries, it was only a small and seemingly ineffective sect. ${ }^{24}$

\section{The Problem of Conscientious Objection to War}

On the basis of the above historical experience as well as that of more recent conflicts, such as the American involvement in Vietnam, a number of problem areas may be identified which confront the military when dealing with the conscientious objector. Firstly, there is the question of whether there will in fact be provision for some sort of legalised conscientious objection, and here it is necessary to examine the relationship of the military to society. Why, indeed, should any society be prepared to make any sort of provision for those who conscientiously refuse to participate in the country's armed forces and, by implication, in the defence of the state?

In this regard, it is instructive to note what sort of societies have demonstrated some degree of tolerance and accommodation to dissent of this kind. In every case, it is the Communist, totalitarian and dictatorial states that have refused to concede anything in this matter and chosen rather to crack down with harsh repressive measures. On the other hand, almost all Western democratic countries have shown at least a sensitivity to the issue, even in times of severe danger. As Brock points out, respect for the rights of at least religious conscience vis-a-vis participation in war has become a recognised part of the Western tradition, and more particularly of Anglo-American political practice. ${ }^{25}$ One may also suggest that such tolerance is indicative of a society based on the freedom of religion and a respect for the views of others, a society, in fact, worth defending against any other state which denies such fundamental liberties to its citizens. An American court once conceded that "funda- 
mental principles of conscience and religious duty may sometimes override the demands of the secular state." 26 It is, however, essentially a question of balance; no society can contemplate such excessive tolerance that its very survival becomes at stake. Finally, it is perhaps the ultimate irony that in those countries where an antiwar stand could arguably be said to have most validity, such as in a Nazi Germany or a communist dictatorship, such a pacifism is most unlikely to be able to function. On the other hand, it may operate to some degree in those democratic societies threatened by such countries, and thereby quite possibly contribute towards weakening them against this totalitarian onslaught.

The other side of the question, of course, relates to why a man should indeed feel obliged to take up arms for his country. Ironically, the following statement by Gandhi, justifying his early involvement in support of British war efforts in South Africa and in World War I, seems to put it in a nutshell: "so long as I lived under a system of government based on force and voluntarily partook of the many facilities and privileges it created for me, I was bound to help that Government to the extent of my ability when it was engaged in a war, unless I non-co-operated with that Government and renounced to the utmost of my capacity the privileges it offered me." ${ }^{27}$ The position of the politically motivated selective objector thus seems especially difficult to justify; after all, since he cannot be selective in his participation in society, there seems little justification for a selective participation in the wars of the state.

The issue is considerably more complicated when one takes into account a religious motivation for a selective objection to the wars of the secular state. As Holmes points out, the Christian has responsibilities to government, but his overriding responsibility is to God. ${ }^{28}$ In any clear-cut two-kingdom theology there is a conflict of loyalties between the two systems. Martin Luther, for instance, was explicit on this point with regard to what to do if one's political master was wrong in going to war. His reply: "If you know for sure that he is wrong, then you should fear God rather than men, Acts 4 (5:29), and you should neither fight not serve, for you cannot have a good conscience before God." However, "if you do not know, or cannot find out, whether your lord is wrong, you ought not to weaken certain obedience for the sake of an uncertain justice. ${ }^{29}$
While such an argument might all too easily be used by the unscrupulous as a cover for malicious political motives, it is difficult to deny its moral force. Many, for instance, would judge particularly harshly the stand of German Archbishop Groeber, who in 1935 rejected the claims of pacifism and supported Hitler, on the grounds that Catholics have always left the decision of the justice of war to the legitimate authorities. ${ }^{30}$ On the other hand, the democratic state may seriously weaken itself against the forces of tyranny should it allow exemption for any sort of selective conscientious objection, given the potential here for abuse and the fact that whatever the underlying motives, a refusal to serve in government military forces constitutes a clear political act against that state. In the greater interests of the whole of which the democratic state is representative, the sincere selective objector must needs be accept with equanimity his penalty, his only consolation being that this is the greater test and demonstration of the sincerity of his passionate witness.

\section{Assessing Conscience}

Assessing the genuineness of a man's conviction is by no means an easy matter. To sit in judgement on another man's conscience is indeed also a serious endeavour and therefore requires that administration in this respect be as fair and objective as possible. The British and American experience, as seen above, is illustrative of some of the difficulties involved here. What proved to be crucial was the spirit in which legislative provisions were interpreted; in different circumstances this could thwart, confirm or even liberalise the original intentions of legislators.

A series of American court judgements indicate particularly well the issues faced when provision is made only for the religious objector who objects to participation in any war. Since the second World War, a series of court judgements have established an "equivalency test" of religious belief. What is required is "a sincere and meaningful belief which occupies in the life of the possessor a place parallel to that filled by the God of those admittedly qualifying for exemption." Nevertheless, this "does not include essentially political, sociological or philosophical views, or a merely personal moral code."31 The overall result has been a collapsing of the distinction that objection be based on religious training and belief into the condition that it be 
conscientious i.e. that it be deeply and sincerely held and derive from the binding obligations of consience, divinely inspired or not. Religion is thus interpreted in a sense which does not exclude secular conscience. Indeed, this illustrates the fact that the division between religious, moral and ethical reasons for a pacifist stand is somewhat artificial and vague, and becomes arbitrary unless terms are particularly well-defined and unambiguous.

Another problem arises in distinguishing between a selective and a universal objection to war. David Malament has pointed out the possibility here of what he has termed a "contingent pacifism". Thus, an objector might well distinguish in principle between just and injust wars, declare his willingness to fight in the former, and yet firmly believe that no actual war such as he might face will be just. This position could possibly be based on a radical political analysis, or perhaps on the judgement that no war is just when waged with indiscriminate aerial weapons. Another derivation might be from a theological doctrine which maintained that only a war ordained by God would be just and that God will (probably) not ordain such a war. This third position is more or less that taken by Jehovah's Witnesses, and an American Supreme Court upheld the right to exemption of a Jehovah's Witness in 1955 despite his declared willingness to participate "in defence of his ministry, kingdom interests, and in defence of his fellow brethren." ${ }^{32}$ Overall, then, an objector to a particular war may contingently really be a universal objector.

Since it is unlikely that claims to conscientious objection will be accepted at face value, a personal statement, references and an interview will usually be required. In addition, a variety of socalled "test case" questions may be put to the putative conscientious objector to war. A popular question, for instance, may be whether he would use force if men came to his door threatening his wife and children. Many would-be conscientious objectors in America have, in fact, told their draft boards that they would, under certain circumstances, "use force". The obvious question here is whether those circumstances constitute states of war. There are numerous American judical decisions to the effect that willingness to defend oneself, or a member of one's family, or a friend, or a stranger attacked on the street does not compromise the position of a conscientious ob- jector. The line is furthermore not drawn at defending groups of people or the immediate community in which one lives. ${ }^{33}$

This whole issue is perhaps cleared up if we accept, as Paskins and Dockrill point out, that there is a substantial sense of the word "pacifism" in which it is not the case that violence is what the pacifist is against. ${ }^{34}$ What he is against is that loss of moral control which is everywhere characteristic of war. A point that often impresses pacifists is the loss of control of one's actions involved in taking part in activities of a military dimension. What differentiates the military is to some extent the degree to which control of one's actions is assigned to others (the soldier's duty to obey orders, to engage in coordinated activity under conditions where much is secret from him etc.) and to some extent the matter in which control is surrendered: others and not I are to decide when I shall kill! ${ }^{35}$

The beliefs motivating such a pacifist need not be religious in nature; as Paskins and Dockrill point out, such a pacifism is most aptly termed a pacifism of scruple since it involves a person who is particularly scrupulous about the precise character of his actions. To kill another person is a deeply problematic proceeding, and one in which he would want to be very sure as to what exactly he is doing. The pacifist of scruple is not necessarily a refuser of all killing, but his problem is with the loss of control of one's own action that is everywhere visible in the conduct of war. Taking now the test case mentioned above, it becomes evident that the situation here is not one of war and the pacifist would be completely in control of his own actions under such circumstances. The problem of the pacifist of scruple is not so much with deciding what to do in such a clearcut moral situation as with putting himself into a series of situations in which he will be called on to perform or participate in actions whose morality is prima facie dubious, cannot be foreseen, and will not be subject to his own judgement. ${ }^{36}$

Finally, there is the matter of what type of exemption from combat service is given for those granted the status of being recognised conscientious objectors. Policy here might turn out to be either punitive or accommodative, and this may be either through legislative intent or occur through the unfair administration of alternative service. Nevertheless, the principle of reasonable compensatory service seems a sound one, 
since the conscientious objector is not required to risk his life or to face the discomfort and inconvenience suffered by the fighting soldier. Different forms of non-combatancy, as well as suitable civilian alternative service, are the options here, and it is important that objectors are correctly allocated in line with the nature of their beliefs e.g. whether or not the wearing of military uniform is acceptable.

Judging from the British and American experience in the two world wars, much consideration will have to be given to ensuring that abuses are kept down to a minimum, and that useful work is assigned which makes full use of the skills and qualifications of the men involved. If handled sensitively and with due regard to manpower concerns, a genuinely useful contribution may be played here by men who would otherwise either languish in prison, cause disciplinary and security problems at army bases or else flee the country. Such men need not be treated punitively or even as slave labour, since by being legislatively provided for they are not criminals in any sense. In any case, it is increasingly recognised that the distinction between combatant and non-combatant has become blurred in modern war, and a contribution in one sphere may aid the attainment of goals in the other

\section{Pragmatic Considerations}

The potential difficulties in accurate classification of objectors, as outlined above, indicates that the Boards charged with testing eligibility need members who are particularly well qualified to take account of such subtleties. Fairness need not be the only reason for ensuring this; there are relevant pragmatic considerations as well. In World War II America, for instance, it has been noted that misclassified objectors "constituted in many instances the most difficult disciplinary problems from the viewpoint of the military and naval authorities. ${ }^{137}$ An American court once noted also "the hopelessness of converting a sincere conscientious objector into an effective fighting man." ${ }^{38}$ One writer has made the observation that there is a limit to what law can do in "requiring" compliance, and the principled pacifist is precisely the person who cannot be reached by the ordinary methods of the law since he has made up his mind not to be moved by force. ${ }^{39}$

Another issue arises in connection with the strictness or otherwise with which official policies relating to exemption are pursued. Malament points out that it may well make good sense to be particularly lenient when applying the letter of the law, since if it is morale that the government is concerned about, it must then weigh the disruption that might result from the deferment of conscientious war opponents against the disruption that results from their presence in the Army or from their conspicuous imprisonment. This latter situation was particularly the case with America's war in Vietnam. Low army morale was exacerbated by the presence within the army of vocal opponents of the war who expressed their feelings, even turning out Gl newspapers and organising open resistance. The centre of the antiwar movement in fact shifted from the college campuses to military bases on the one hand, and to the federal prisons on the other. ${ }^{40}$

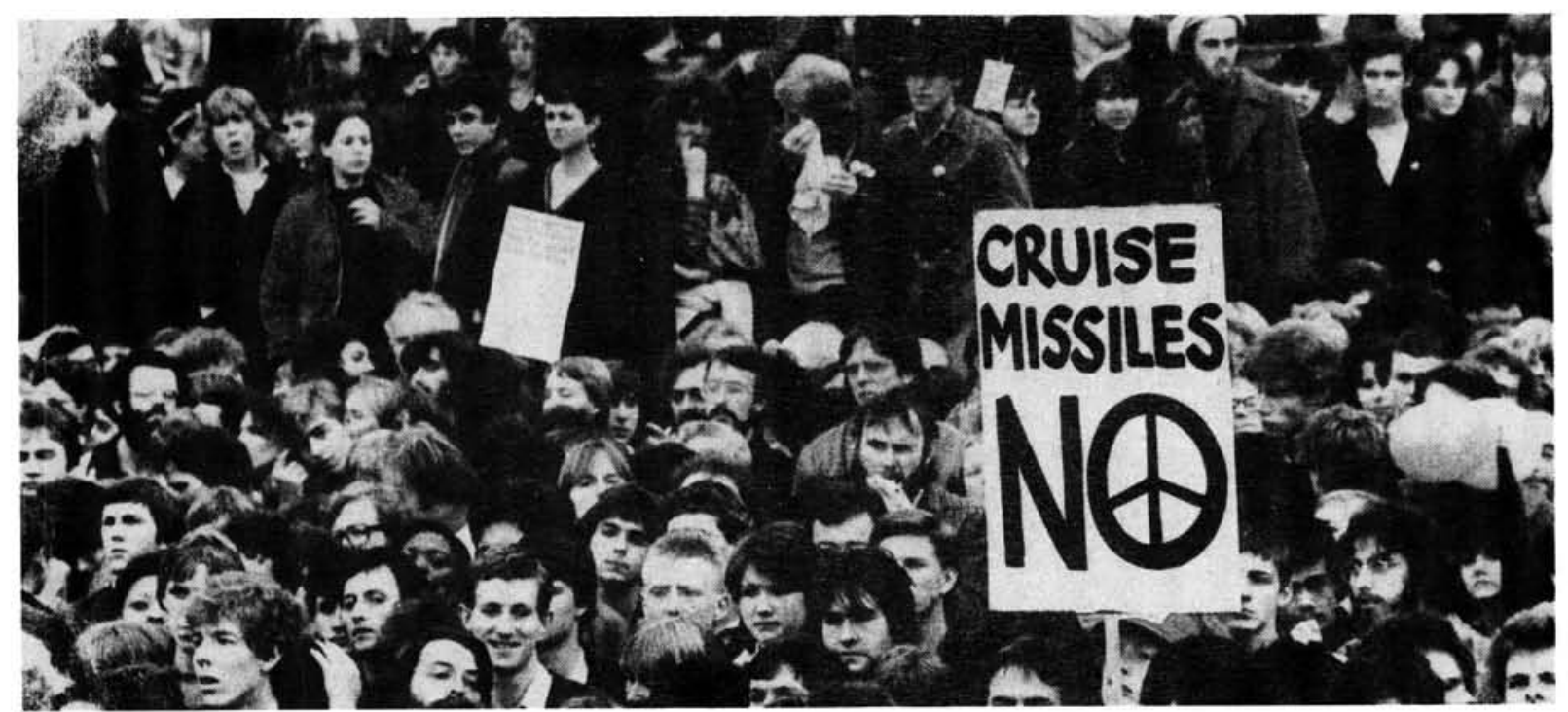

A Trafalgar Square demonstration organised by the Campaign for Nuclear Disarmament (Time, April 6, 1981) 


\section{The Threat of the "Peace Movements"}

Aside from the issue of individual conscientious objection to war, a much more serious problem on the world scene today relates to the various, sometimes inchoate, self-proclaimed "peace movements". Although there is nothing particularly new about these bodies, what is now significant is the scale of the threat they pose to rational and reasonable Western efforts to counter Soviet aggressive intentions. It is important, therefore, to understand the nature, goals and origins of these movements.

The general reactivation of the British and West European anti-nuclear movement may be traced back to 1977 after the Russians began deploying, and aiming at Western Europe, many of their new, 5000-kilometer range SS-20 nuclear missiles. When the United States later proposed installing countervailing missiles many Europeans feared nuclear war. The US Senate's rejection of the Salt II agreement, President Reagan's denunciation of detente, and incautious Amrican talk of limited nuclear war in Europe fed these fears and gave impetus to the current peace movement's growth. ${ }^{41}$

The peace movements have managed to capture public attention in four of the five NATO countries scheduled to receive U.S. Cruise and Pershing 2 missiles, namely, West Germany, Britain, the Netherlands and Belgium. Particular support seems to be forthcoming from ecolog- ists, youth organisations and Church groups. In politics, the anti-nuclear and ecologist "Greens" now have seats in the Bonn Parliament for the first time, a development some attribute to a growing ohne mich (count me out) syndrome, a rejection of involvement in the contest between the superpowers and a reluctance to shoulder greater defence burdens. ${ }^{42}$ In Holland and Belgium the anti-nuclear influence runs so deep that fragile centreright coalitions are delaying until the last moment decisions on authorising the missile deployments. In general, the Labour and Social Democratic parties in Britain, West Germany, Holland, Belgium, Denmark and Norway, have all modified their previous support for Nato's nuclear strategy in response to pressure from this anti-nuclear movement. ${ }^{43}$

It is important to realise that the anti-nuclear movement as a whole represents a coalition of diverse interest groups. The anti-nuclear campaigners of today are a more mixed lot that the ban-the-bomb marchers of the late 1960's. The main co-ordinating bodies are organisations which include most colours of the political rainbow: strict pacifists, Christian idealists, Communists, feminists, conservatives, ecologists and those who are just anxiety-stricken. Nevertheless, what is common is more than a tinge of antiAmericanism and a hard core of unilateral disarmers. This is indicative in the fact that the brunt of protests are directed at the U.S. missiles to be deployed by Western Allies - not at missiles already aimed at Western Europe by the Soviet Union.

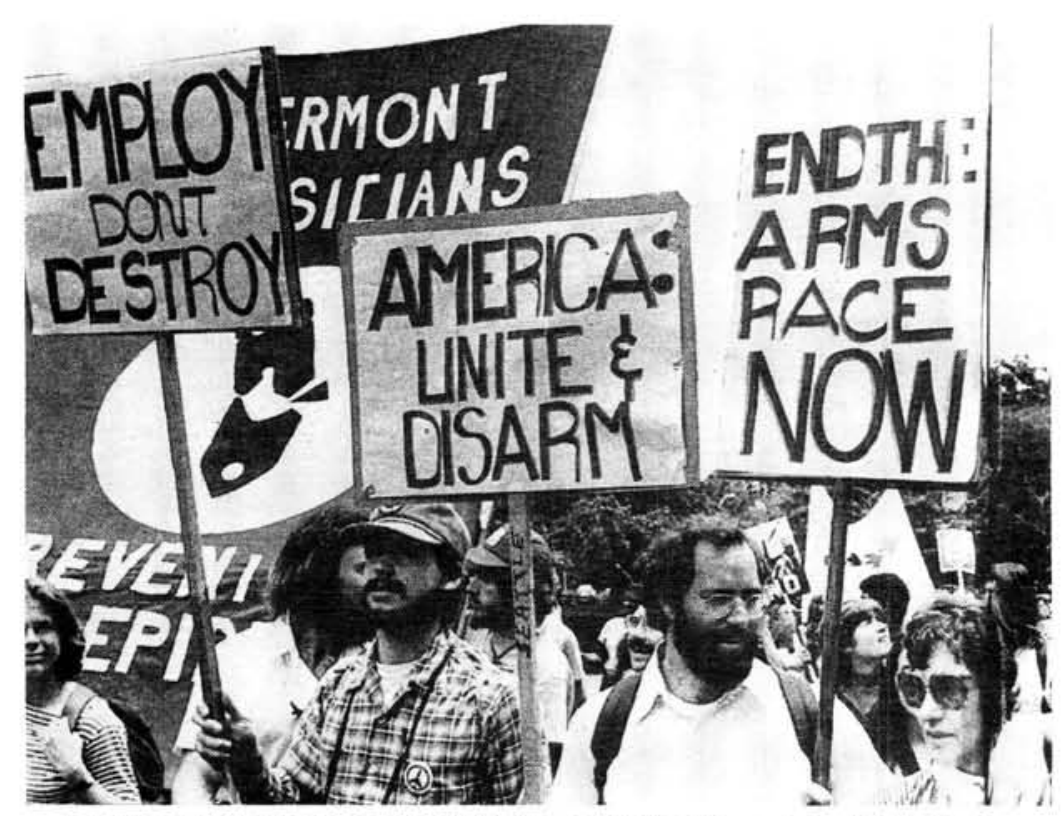

American student protesters (US News and World Report, Aprll 25, 1983) 


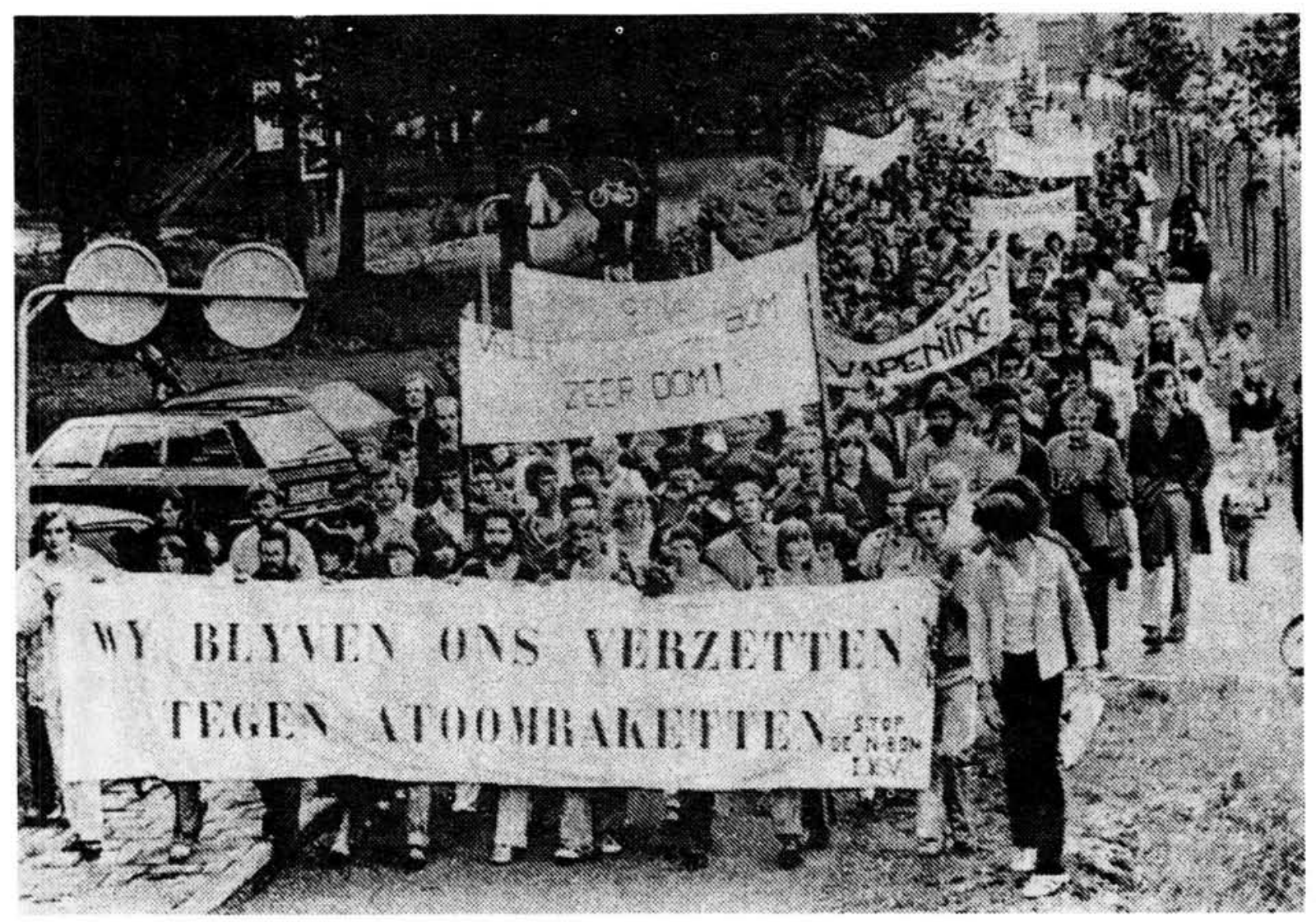

Anti-nuclear demonstrators in Holland (Time, April 6, 1981)

In view of the manner in which these developments so manifestly aid the foreign policy goals of Moscow, the question arises as to the degree to which these movements are manipulated and directed by Soviet Communists. Frank Chapple has uncompromisingly stated the position as follows:

\section{"... reactivated 'peace' groups now mush- rooming around Europe have either been created or are being manipulated by pro- Soviet apologists in one of the most bril- liantly orchestrated propaganda offensives \\ run by the communist front World Peace Council in Helsinki and master minded by the Kremlin ... Their goal: to cajole and frighten Western Europeans down a road leading from unilateral disarmament to iso- lationism and ultimate defenselessness against political aggression" 44}

An Intelligence Digest World Report comments that the contradiction within the words "Peace War" contains the essence of this powerful Communist weapon. The use of the "desire for peace" as a communist revolutionary weapon was clearly established as far back as 1922 , when Lenin advised the Soviet Commissar for Foreign
Affairs that "we consider it to be our duty to support ... pacifists in the bourgeois camp ... (this) will help to demoralise the enemy." Giorgi Dimitrov, who became head of the Comintern, once stated that "one (peace) sympathiser is generally worth more than a dozen militant communists. A writer of reputation, or a retired general, are worth more than 500 poor devils who don't know any better than to get themselves beaten up by the police." 45

The plans for the modern peace offensive were clearly outlined at the 1969 International Conference of Workers' Parties in Moscow, where it was agreed that "popular movements in the West can play an essential role in advancing socialism and peace." Since then, plans have been developed to involve many organisations such as trade unions and churches, while there has also been a special focus on influencing women. ${ }^{46}$ As Alun Chalfont points out, however, the true role of the Soviet Union in the encouragement and exploitation of "peace movements" is more subtle and effective than is suggested by any simpleminded model of Russian conspiracy. The term "active measures" is used by the Soviets to describe a broad range of operations designed to promote foreign policy aims. These active meas- 
ures include "disinformation", manipulation of the foreign press, and the use of "front organisations" to expand Soviet political influence. In the context of the unilateralist movement, the relevant front organisation is the World Peace Council, which provides an umbrella organisation for a number of pro-communist "peace movements" from various countries. The WPC has been successful in attracting the support of many pacifist and left-wing militants, some of whom are not fully aware of the extent to which it is controlled from Moscow. ${ }^{47}$

A particularly revealing example of the scale and effectiveness of this "active measures" approach can be seen in the success of the Moscowinspired campaign against the neutron bomb in the mid- to late-seventies. A top Hungarian Communist Party official was later to declare: "The political campaign against the neutron bomb was one of the most significant and most successful since the second world war. We think it is our common interest to make greater efforts for the implementation of the peace programme for the strengthening anti-imperialist unity." 49 Just how successful Russian efforts have been may be gauged from the comment of one KGB agent that "if Moscow decides that 50000 demonstrators must take to the streets in Holland, they will take to the streets. ${ }^{49}$

In a brilliantly incisive analysis, Alun Chalfont lays bare a particularly insidious aspect of the Soviet "peace offensive", namely, the debasement, abuse and corruption of language. The model used is that of Newspeak, the sinister and corrupt language used in George Orwell's classic novel of the totalitarian nightmare, 1984. Orwell's invention of Newspeak was designed to underline the fact that the degradation and debasement of language is a routine instrument of indoctrination and deception, and that one of the unmistakeable symptoms of a demoralised society is the ready acceptance of Newspeak as a form of communication. Contemporary examples of this include the fact that armed terrorists seeking to overthrow a legitimate government by organised violence become described as "freedom fighters", while men who kill innocent people at minimal risk to themselves are dignified as "urban guerillas". A Moscow published guide to political terms defines the arms race as "arms manufacture on an ever-increasing scale carried out by aggressive circles of imperialist states". Under the heading of AGGRESSION the sole examples given are "the United States' war against the Vietnamese people and Israel's actions against Arab states." 50

It is in this context that Chalfont claims that the word "peace" has been kidnapped by the various protest movements. The sad result has been that rational debate about nuclear weapons can only but be abortive if one side is allowed blandly to describe itself as "the peace movement", implying the simple-minded corollary that those who disagree with it must be in favour of war. If one furthermore couples this observation with the observed Russian manipulation of the peace movements one sees that it is actually a Newspeak peace that is sought. As Lenin once put it: "as an ultimate objective, peace simply means Communist world control ..." 51

The frequent counterargument to this is that by far the great majority of members of organisations such as the Campaign for Nuclear Disarmament (CND) are sincere, idealist men and women with no ulterior political motives, driven only by a passionate desire for a world at peace.

Chalfont's forthright answer here is that many of these people are simply the dupes of unscrupulous political manipulators, while many others are bigots who are persuaded that there is a "quick fix" for the intricate problems of national defence, international security, East-West arms control, and general disarmament. This conclusion should actually be no surprise, since it is a persistent Leninist theme that Communists should be prepared to deploy every strategem, device and deception to achieve their aims, using anyone they can exploit or manipulate. The rapid growth of the CND during the sixties, for instance, coincided with the rise of the Trotskyist movement, whose leaders were quick to recognise its potential value. As a result, Communist and leftist members are disproportionately represented amongst the CND leadership. Chalfont thus comments that the aims of movements such as CND are not entirely circumscribed by a concern for arms control or disarmament, but rather, they are political organisations of the left, giving protective colouration and bogus respectability to people for whom the emotional appeal of peace and disarmament is merely an instrument for the prosecution of more comprehensive political aims, and who are prepared to exploit the genuine fears of others to achieve them. ${ }^{52}$

An instructive parallel may perhaps be drawn with the naiveté of the pre-World War II pacifist movement. Brock points out that pacifist publi- 
cists of this time, ignorant of the historical background of Central Europe, only too often served up the German viewpoint and pleaded for its consumption on grounds of moral principle. ${ }^{53}$ In a not ignoble desire to avoid war they confused a principled pacifism with the politics of surrender. The Munich crisis of 1938 "finally exposed the weakness of pacifist political propaganda." Like most people in the West, pacifists found it hard to comprehend the potentiality for evil of the Nazi and other totalitarian regimes and their capacity to dupe their own people by the mass communication media. Against such regimes, neither appeasement nor pacifist theories of non-violent resistance could possibly prevail.

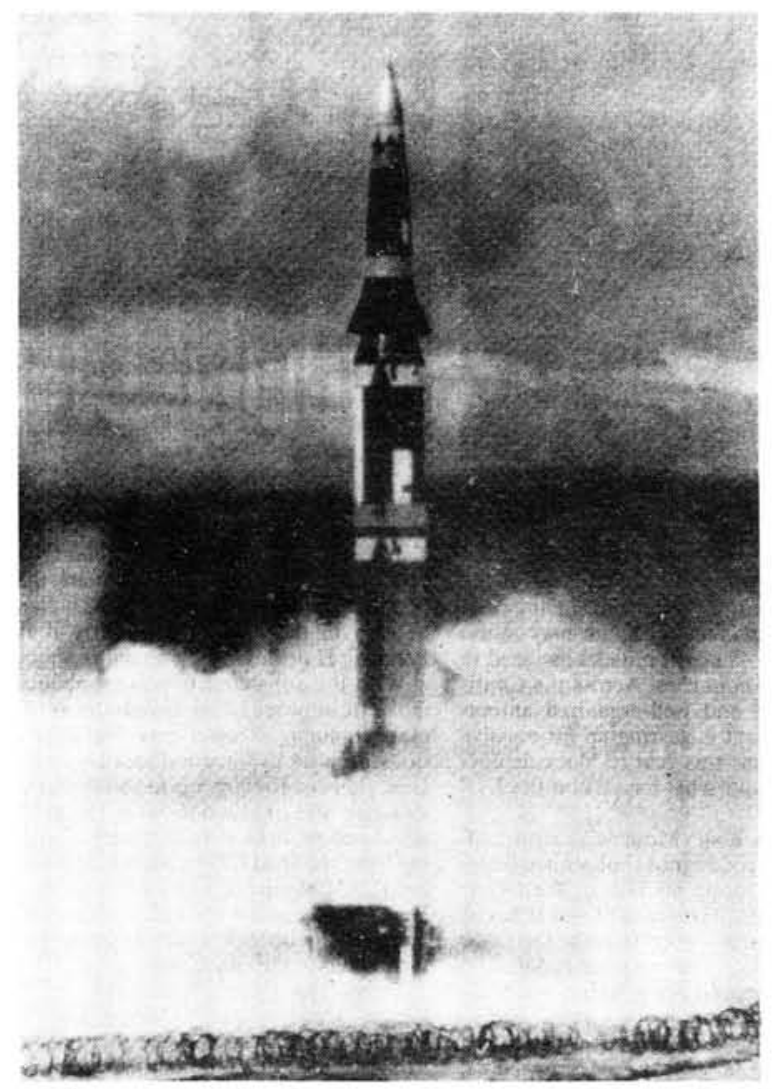

cause they exist as islands in the midst of a powerful and cohesive Western alliance of democratic nations. If that alliance were to disintegrate (which is the inevitable consequence of unilateralist policies) the whole of Western Europe would degenerate into a collection of "neutral" nation-states, whose model is more likely to be that of Finland than Sweden or Switzerland. The Soviet Union will then have achieved one of its principal foreign policy aims - the "Finlandisation" of Western Europe. What this means is that the nations of Western Europe, deprived of their collective security, would rely for their continued existence entirely upon the benevolent intentions of the Soviet Union. ${ }^{54}$

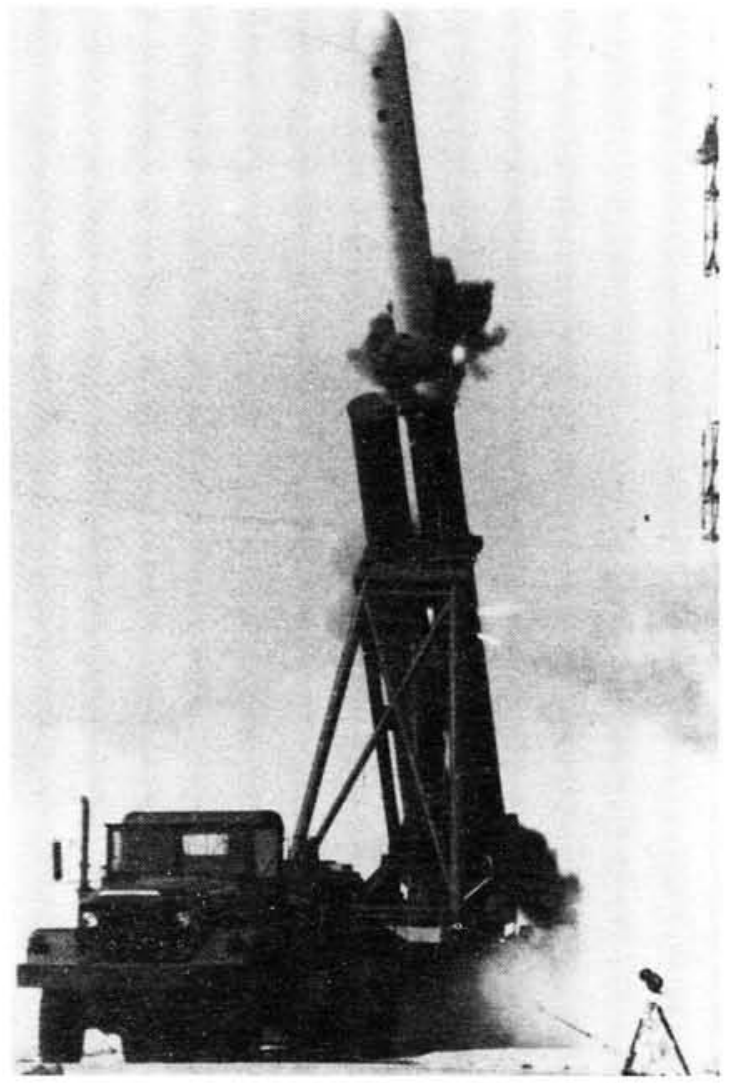

The centre of the European controversy: US Pershing II (Newsweek, January 31, 1983) and ground-launched cruise missiles (Nato's Fifteen Nations, September 1982)

\section{The Dangers of Unilateralism}

Chalfont argues that the logical conclusion of any unilateral renunciation of nuclear weapons by a country such as Britain is a slide into neutralism, a position endorsed by a great majority of the "peace" people who believe that there is really little to choose between the Russians and the Americans. These people are wont to point to Sweden and Switzerland as successful examples of "neutralism". This ignores the fact, however, that both these countries are able to enjoy the luxury of neutrality almost entirely be-
Much of the dangerous complacency about Russian intentions derives perhaps from a fundamental misunderstanding of military power. Military forces are, in fact, not designed solely, or even principally, for use in war; their very existence is an instrument of foreign policy. The Soviet political leadership would naturally prefer to achieve its aims without open conflict, and it realises that this is best able to be done if it is able to confront a potential adversary, in any confrontation of will, with an overwhelming manifestation of force, with which it can blackmail, 
terrorise and coerce. One has only to look at post - Solidarity Poland to realise the truth of this observation.

The real danger of Soviet domination of Western Europe thus does not lie in an invasion of Western Germany by Russian armoured divisions, although this cannot be ruled out especially given the deterioration of Western conventional defenses. A much more probable contingency is that the Soviet Union might achieve its aims without firing a single shot. Almost certainly, this will happen if the West has abandoned the will, the military resources, the collective deterrent and defensive system with which it can resist threats and blackmail. It is for this reason that unilateral disarmament by the West poses such appalling dangers.

The argument of some unilateralists, however, is that if Britain, for instance, was to abandon its nuclear weapons, "others" would follow suit, and the way would be open for an end to "confrontation" and the establishment of a world of stable and powerful "coexistence". Chalfont's rejoinder here is that this must surely qualify as the definitive triumph of wishful thinking, of hope over experience. The sober fact is that "unilateral disarmament" by Britain would have absolutely no effect on the policies of other countries which possess, or are planning to possess, nuclear weapons. It's sole consequence would be to remove one incentive for others to disarm, since in the complicated real world of international affairs, concessions are made only in exchange for similar and simultaneous concessions by the other side. To quote Michael Stewart:

\begin{abstract}
"Unilateralism is the enemy of multilateral agreed disarmament, just as it is the enemy of conciliation: in effect, whatever the intentions of those who preach it, it is the enemy of a real and lasting peace." 55
\end{abstract}

To conclude, the overall message from Chalfont's most penetrating analysis is that it is important to resist the temptation to regard the "peace" people as misguided but harmless idealists. The directorate of the unilateralist movement constitutes a hard left-wing political organisation; what is unique about it is that its political aims are concealed under the slogans and pretensions of a moral crusade. What lies at the end of the road that begins with ritual chants of "Ban the Bomb" and "No Cruise, No Pershing" is no less than the disintegration of the West's system of collective security and the inevitable consequence of the erosion of political freedom.

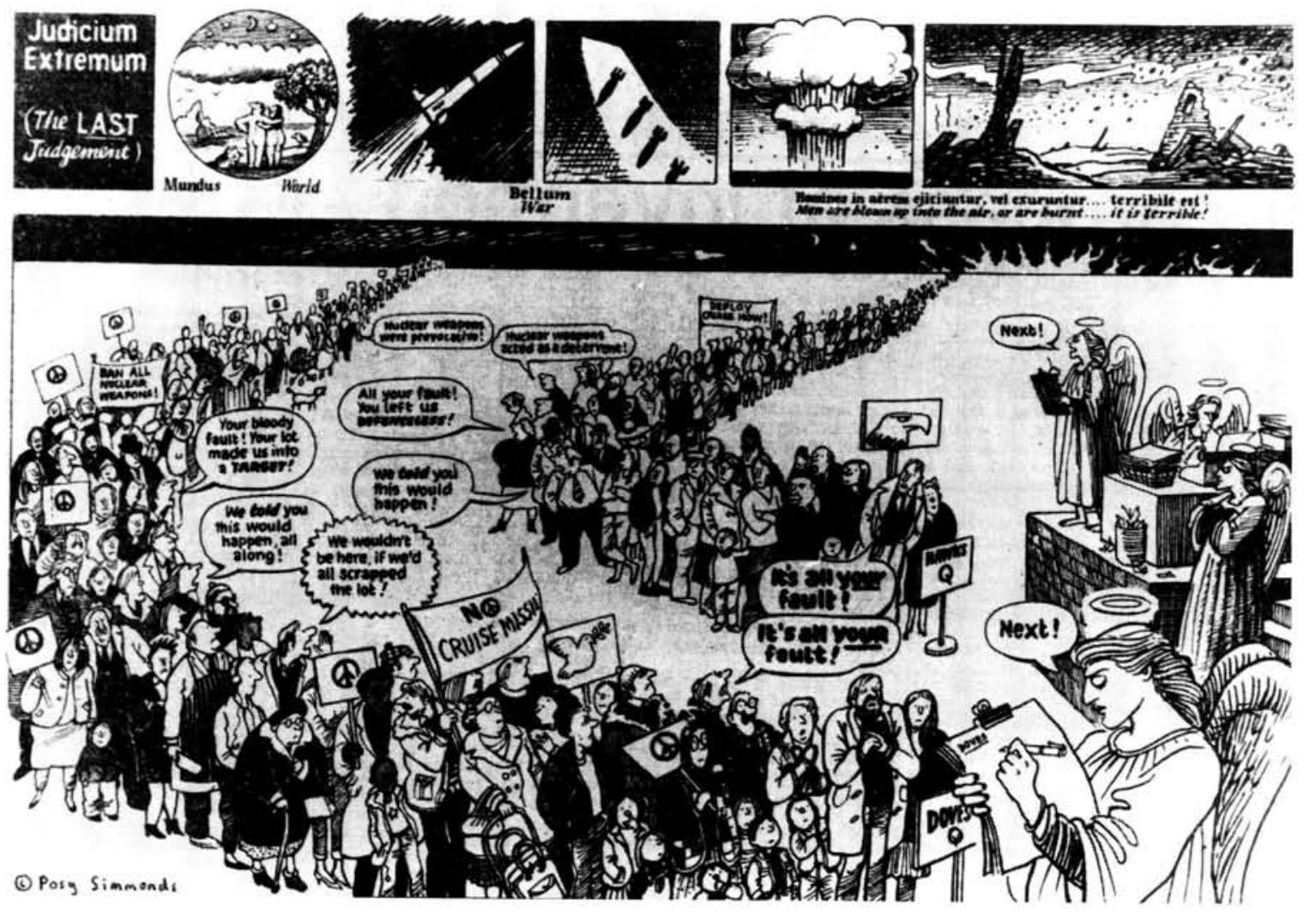




\section{Pacifism and the Moral Dilemma of War}

In the light of the above analysis, a pertinent question is whether one is thereby entitled to dismiss altogether the claims made by pacifists on the subject of war. Firstly, it is only fair to point out that in terms of the definition offered earlier, it is only in a very loose sense that one can actually term the modern-day "peace movements" as unambiguously pacifist. Such movements are really a coalition of diverse groups, amongst which the strict pacifists are an acknowledged minority. Furthermore, as Brock is at pains to point out, just as there are cleavages in the wider peace movement, so also are there cleavages within the pacifist camp. ${ }^{56}$ Over against those pacifists supportive of a leftist revolutionary stance, there are those who have remained profoundly sceptical of Communist aims and merely wish to register a personal protest against what they see as something in itself so heinous that its use under any circumstances is unjustified.

Having said this, it must be acknowledged that the moral significance of the pacifist position derives from the view it takes of war and the extreme rejectionist stand it has adopted in this connection. Such a moral stance simply cannot be dismissed without at least posing a moral counterargument, particularly since there are questions of religious principle at stake. As Brock points out, pacifism presents in most acute form the problem of the place of morality in political life, and furthermore, this is particularly true of Christian pacifism. ${ }^{57}$ It is certainly the case that of all the moral problems confronting man, war is the greatest. In arguing this point, O'Brien notes that war has always been a wasteful, destructive, deplorable institution which inflicts great, often indiscriminate, suffering on belligerents. Indeed, the best that most reasonable men who are not pacifist can say today is that war may be a necessary evil. ${ }^{58}$

\section{Radical and inconsistent}

Arguing from a philosophical standpoint, Jan Narveson identifies the pacifist belief as being not only that violence (war) is evil but also that is is morally wrong to use (military) force to resist, punish or prevent such violence. This necessarily makes pacifism a radical moral doctrine and, argues Narveson, it is furthermore actually incoherent since it is self-contradictory in its fundamental intent. Thus, if the whole point of pacifism lies in its opposition to war, what if military force is rationally the only way to prevent such war? It is perfectly possible to see that in some circumstances a person who is genuinely against war may necessarily have to use military means as the only available way of opposing that to which the pacifist is opposed, namely war. Narveson's damaging accusation here, therefore, is that either the pacifist's opposition to war is not genuine, or he cannot be a consistent pacifist. ${ }^{59}$

\section{Corrupted by self-righteousness}

One may link this above criticism with the stand taken by the ex-pacifist theologian Reinhold Niebuhr. For Niebuhr, pacifism still retained raison d' etre within the church only if it eschewed all attempts to claim political relevance. In this view, the other worldly defenselesness of groups such as the Mennonites witnessed to a legitimate striving for perfection in a fallen world; it represented "a genuine impulse in the heart of Christianity." Niebuhr's argument is directed not at the pacifism of a sect which draws apart from the world, but rather to the pacifism of people in the world, who do not want to be withdrawn from it. The dilemma for such people is that where the objective situation presents only a choice between submission to injustice or war (both admitted Christian evils), war might be less inconsistent with the law of love than not to fight. Niebuhr charges that the pacifist witness is thus usually corrupted by self-righteousness. It simply fails to acknowledge the necessity of making imperfect choices in a sinful world. Since all men are sinners, Christians are not thereby exempt from the obligation of resisting evil in others, or else no human action would be possible. Pacifists cannot therefore pretend that by sacrificing justice to non-violence they are thereby absolving themselves from guilt. ${ }^{60}$

\section{Misleading high ideals}

Another aspect of this morally abdicative side of pacifism is laid bare in the critique by Elisabeth Anscombe. Her observation is that since pacifism everywhere commands at least a sentimental respect, its influence has been enormous, far exceeding its influence on its own adherents. This influence has, however, been misleading in that pacifism lays a mistaken emphasis on highsounding and strict principles. As Anscombe points out, such adherence to unattainable ideals is a trap, the danger being that since one is unable to follow the ideal of absolute pacifism, and one is thereby committed anyway to "compromise with evil", the temptation is to go the whole hog and wage war totally without limit. 
Inadvertently, pacifism therefore teaches people to make no distinction between the shedding of innocent blood and the shedding of any human blood. Many people have thus been corrupted, since seeing no way of avoiding the wickedness of war, they set no limits to it. A case in point is the Allied policy of obliteration-bombing German cities in World War II, a policy with shaky justification even in pure military terms. What Anscombe charges is that pacifism and the widespread respect for pacifism have led to a universal forgetfulness of the strongly-entrenched Judeo-Christian teaching against the shedding of innocent human blood. ${ }^{61}$

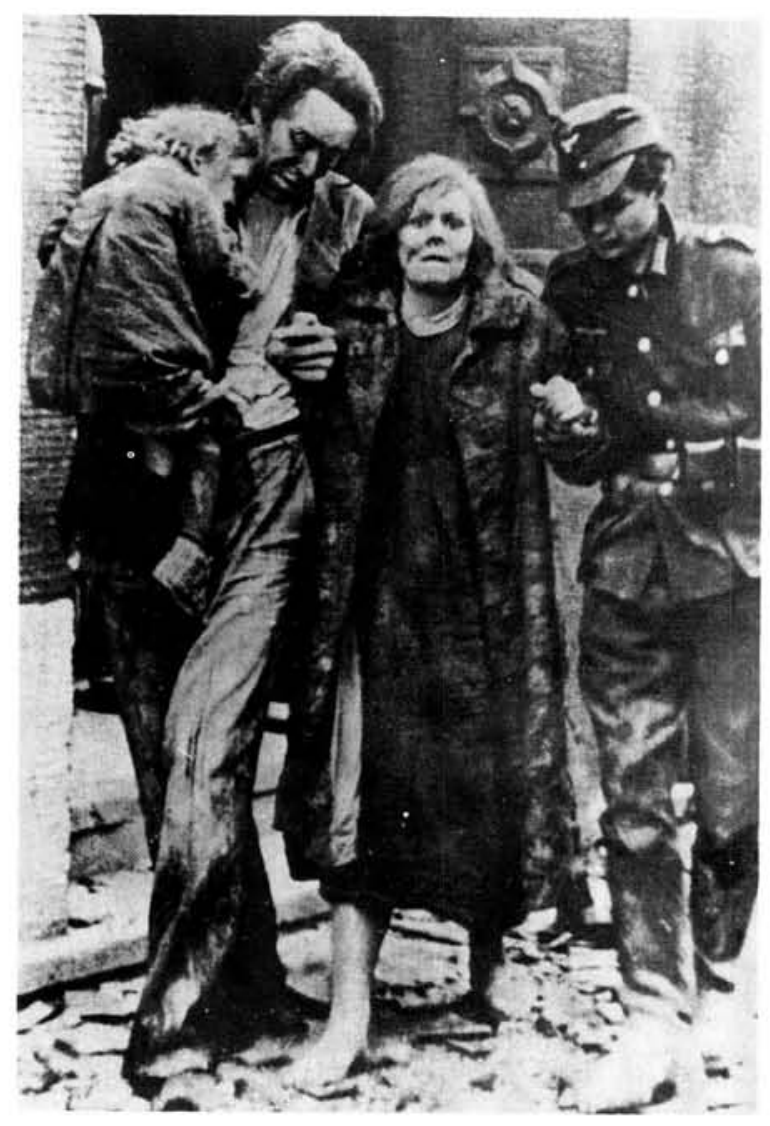

The clvillan agony of WWII - war is no longer fought only between combatants

\section{Christian response to war}

As Wasserstrom points out, the strongest argument against war is that which rests upon the connection between the morality of law and the death of innocent persons. ${ }^{62}$ In war, no less than elsewhere, the knowing killing of the innocent is an evil that throws up the heaviest of justificatory burdens. To the perennial question therefore of whether war is ever morally justifiable, there have been two responses in Christian ethics: the negative response of pacifism and the positive response of the just war theory. ${ }^{63}$ Bailey comments here that the Just War doctrine is today, explicitly or implicitly, the ethical position of almost all non-pacifist Christians, but there has always been a pacifist minority within the Christian Community dating back to the time of the early Christians. ${ }^{64}$ Holmes points out that the function of the centuries-old just war theory has been not to justify wars but to judge them, to criticize and thereby as far as possible prevent the use of force and to work for the abolition of war. ${ }^{65}$ Martin Luther's stand, for instance, was that war is only justified out of necessity, as a last resort, and even then with just intent and limited means, ${ }^{66}$

\section{The Concept of Limited War}

In the context of this type of ethical thinking, the position of William O'Brien is of considerable interest. Taking a firmly realist perspective. O'Brien argues strongly for a critical reexamination of the concept of limited war. What this concept involves is that all recourse to armed coercion be limited in ends and means in every way possible. Since the elimination of war is impossible in the real world, men must therefore accept the reality and necessity of armed coercion and learn how to limit and channel it insofar as possible in the interests of the community. The limited war concept is of armed force as an instrument of policy, and not as an end in itself. At times, perfectly legitimate military necessities may need to be subordinated to the necessities of political policy. O'Brien argues that Clausewitz is correct in his submission that war is a continuation of politics by other means. However, he is wrong to the extent that he can be interpreted as contending that once war is unleashed it has its own built-in logic and necessities which must be pursued relentlessly. Indeed, in a substantial sense, the aim of war is not "victory" but rather it is to obtain legitimate political and military ends, the definition of which, as well as the means, is ultimately the responsibility of the political authorities. ${ }^{67}$

O'Brien gets to the core of the contemporary dilemma when he points out that a major nuclear war would not fit into the concept of armed force as an instrument of politics except as a politics of ultimate despair, bitter retribution, and indefensible revenge. The uniqueness, both material and moral, of the nuclear dilemma is that nuclear armaments and supportive delivery systems 
exist in order that they will not be used. If they have to be used, they have failed. However, there must still be the capability and will to use them, otherwise they will probably not serve the deterrent function which is their only rational and morally defensive raison d'etre. The very great destructiveness of a major nuclear war, as well as the impossibility that it could be waged without large-scale direct attacks on innocent noncombatants, means that it is unlimited and therefore immoral war pár excellence. Pending genuine multi-lateral disarmament, however, mutual nuclear deterrence has a perfectly defensible moral rationale especially since it has successfully kept peace between the superpowers for over thirty years. ${ }^{68}$ The problem is that of "accidental" war and here Lewy reminds us that unless the absurd immorality of a world nuclear conflict is kept in mind and reaffirmed constantly, nations may lose the sense of restraint which today makes nuclear arsenals a deterrent threat rather than weapons readily used. ${ }^{69}$ There seems good reason to believe that the dangers of escalation are such that nuclear war should represent a threshold that ought never to be crossed. Most ominously, talk of "limited nuclear war" is itself a kind of Newspeak, since it puts into acceptable language a contingency which would involve the violent deaths of millions of people.

\section{Pacifist's moral dilemma}

On the level of the pacifist refusal to support or participate in conventional war, there are also some cogent moral criticisms one can take of his stance. O'Brien observes that there is no tension for the pacifist between a possible need for war, or certain methods of war, and the need for peace with justice. Since he is simply against all war, there is none of the ambiguity, the agonising indecision of those who uphold the right to go to war when necessary but also nevertheless seek to influence the conduct of war so that it could be at all times as limited as possible. ${ }^{70}$ If the pacifist is able to escape this dilemma, he is only faced with another set of dilemmas which are no less acute. Thus, as a result of his actions, there will be no restraint on war and the innocent may suffer unnessarily. Furthermore, as Bailey points out, he faces the problem of whether his renunciation of armed force is compatible with responsible citizenship in a substantially non-pacifist

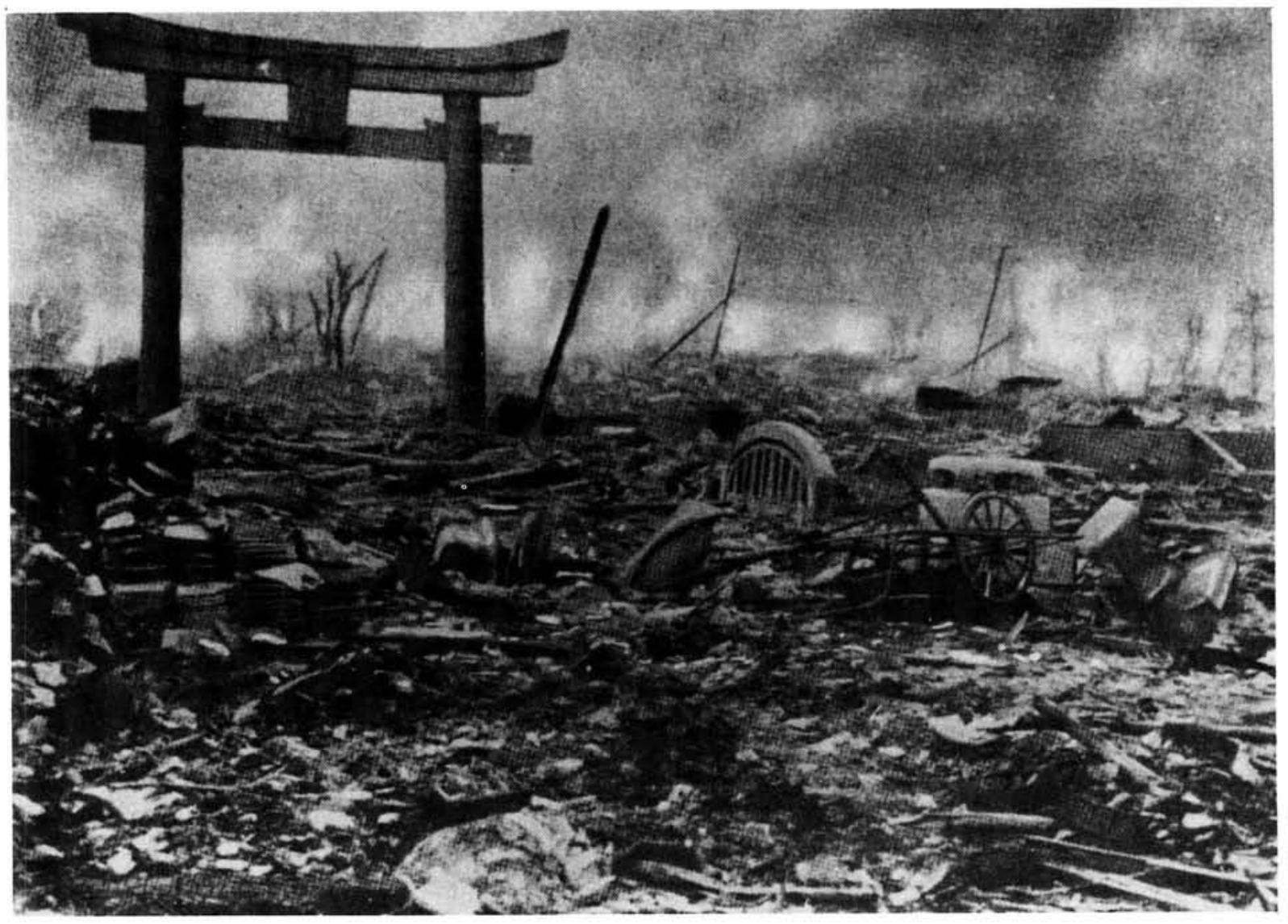

The nuclear nightmare of Nagasaki 
world. Is his pacifism to be a vocation for the few, or a workable and practical alternative? While it may be all very well for the pacifist to indulge in the private luxury of pacifism, this option is not open to the state, which has the interests of others to consider. As George Orwell pointed out, "Pacifism refuses to face the problem of government and pacifists think always as people who will never be in a position of control. ${ }^{.71}$

\section{Naive idealism}

Far from aiding in the work of limiting war so that it conforms with moral dictates, pacifist idealists and the Church have often obstructed this with simplistic slogans and statements. To take one example, Pope Pius XII's theme was that "nothing is lost with peace; all may be lost with war." As O'Brien points out, this is simply not true. A great deal may be lost by peace, perhaps values of such importance and on such a scale as to render the decision for avoidance of war disproportionate and irresponsible. Those who argue "better red than dead" have simply not experienced, say, the horrors of a totalitarian Communist dictatorship which in a purge of all dissenting idealists and religionists may ensure that they become both red and dead. The reality is that there can be disproportionate, unjust peace as well as disproportionate unjust war. There would have been peace in Europe in 1940 if the British had made a deal with the Nazis. As the Holy Father would have looked out on a peaceful Europe under such a regime he would have seen some things that would have been every bit as wrong and inhuman as the dreadful suffering brought about by the Second World War. Granted, a great deal is always lost with war, but great evil exists in the world today because of war which was not fought or which was fought and lost. ${ }^{72}$

To be sure, the Church and most pacifist idealists do not explicitly argue for peace at any price. However, as O'Brien points out, their naive pronouncements on war-peace issues implicitly encourage belief in and action in the direction of "peace at any price". In August 1939, Pius XII was addressing, among others, two totalitarian powers practicing genocide as standard operating procedure and plotting the division of a helpless Poland, his appeal being: "Let men return to mutual understanding. Let them begin negotiations anew, conferring with goodwill and with respect for reciprocal rights." One can be forgiven for thinking that this was simply back to
Munich! O'Brien points out that 1939 was a time for just war, since it was justice that was at stake. Sadly, he comments, the Church and pacifist idealists had failed at that time to prepare men for a war that was just and limited. As a result, the war was waged without limits and provides an illustration of the excesses this so needlessly led to. $^{73}$

\section{Ethical thinking and military utility}

Prime examples from the Second World War where criticism of military policies on ethical grounds also has pragmatic justification include the two atomic bombings on Japan and the British obliteration bombing of German cities. With both incidents, historians have uncovered evidence that they could quite probably have been avoided with little military disadvantage had a more careful evaluation of options been carried out. ${ }^{74}$ The American and British non-insistence on limited objectives led to demands for unconditional surrender which arguably actually lengthened the war. Popular German resolve was stiffened and powerful Japanese peace factions, including the Emperor, were weakened in pressing their case. All this was apart from the tremendous tragedy of the deaths of hundreds of thousands of civilian non-combatants. One must remember also that it was in part the unrestrained vindictiveness of the peace of Versailles that was to sow the seeds of a second devastating world conflict.

Another happy coincidence between moral dictates and military goals occurs in that aspect of ethical and religious thinking about war which relates to the way in which the enemy is viewed. Pope Pius XII for instance, made it clear that "while defending faithfully and courageously his country, a Christian must, however, abstain from hating those whom he is obliged to combat." 75 This may be seen as an application of the injunction to "love the sinner, hate the sin." This ethical demand can indeed be consonant with military utility. As Paskins and Dockrill point out, the American experience in Vietnam has made popularly familiar the importance of the way the enemy is understood. Once grant that the enemy are "gooks" or "terrs", in other words sub-human, and you have not only given up all moral restraint but you have also committed the cardinal military error of misperceiving and thus misjudging the enemy. ${ }^{76}$

The moral lesson is that to obtain and preserve a sense of proportion is to retain a sense of one's 


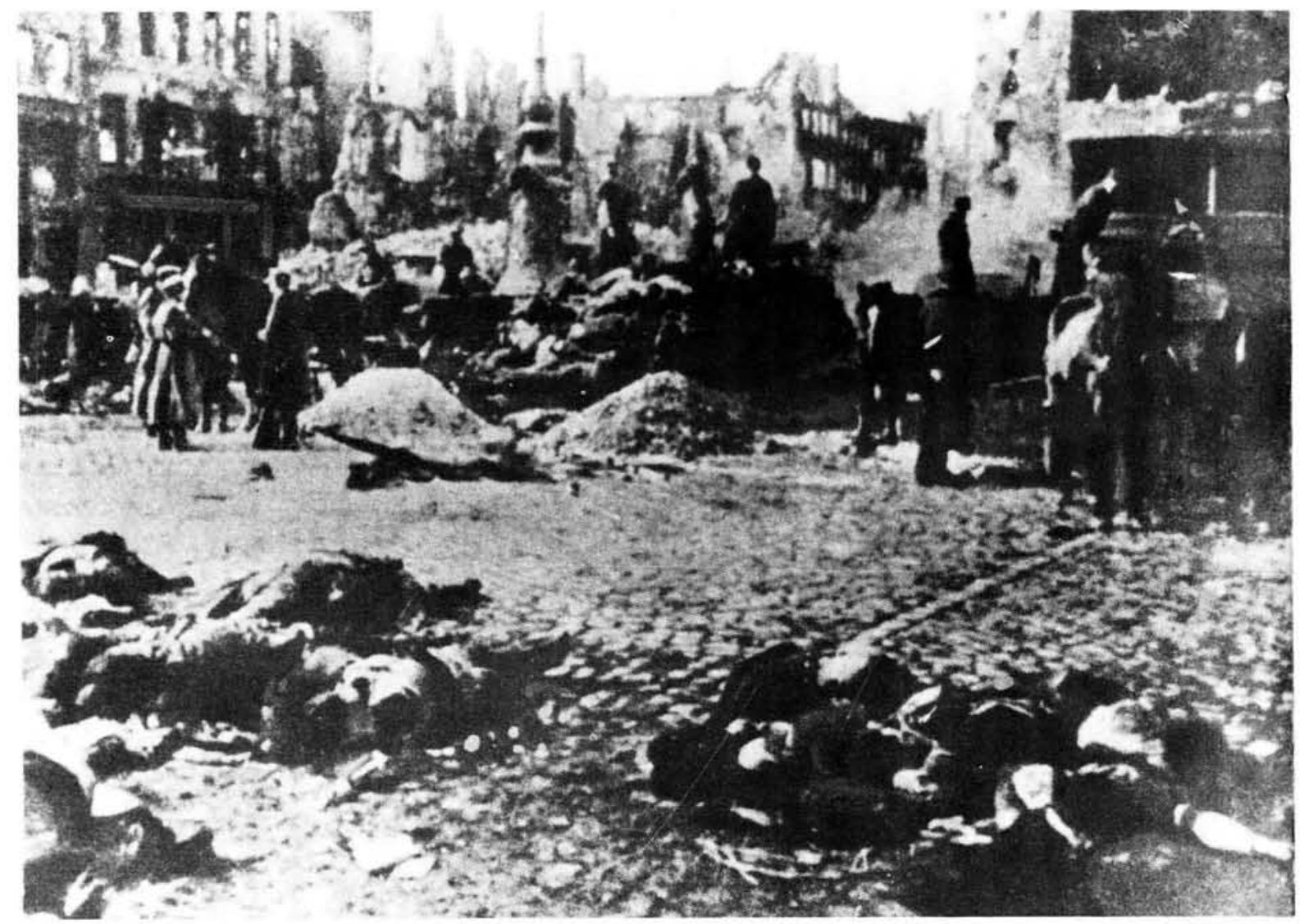

Aftermath of the Allied bombing raid on the refugee-filled city of Dresden in 1945. An estimated 130000 dead and bodles burnt in the streets to prevent epidemics.

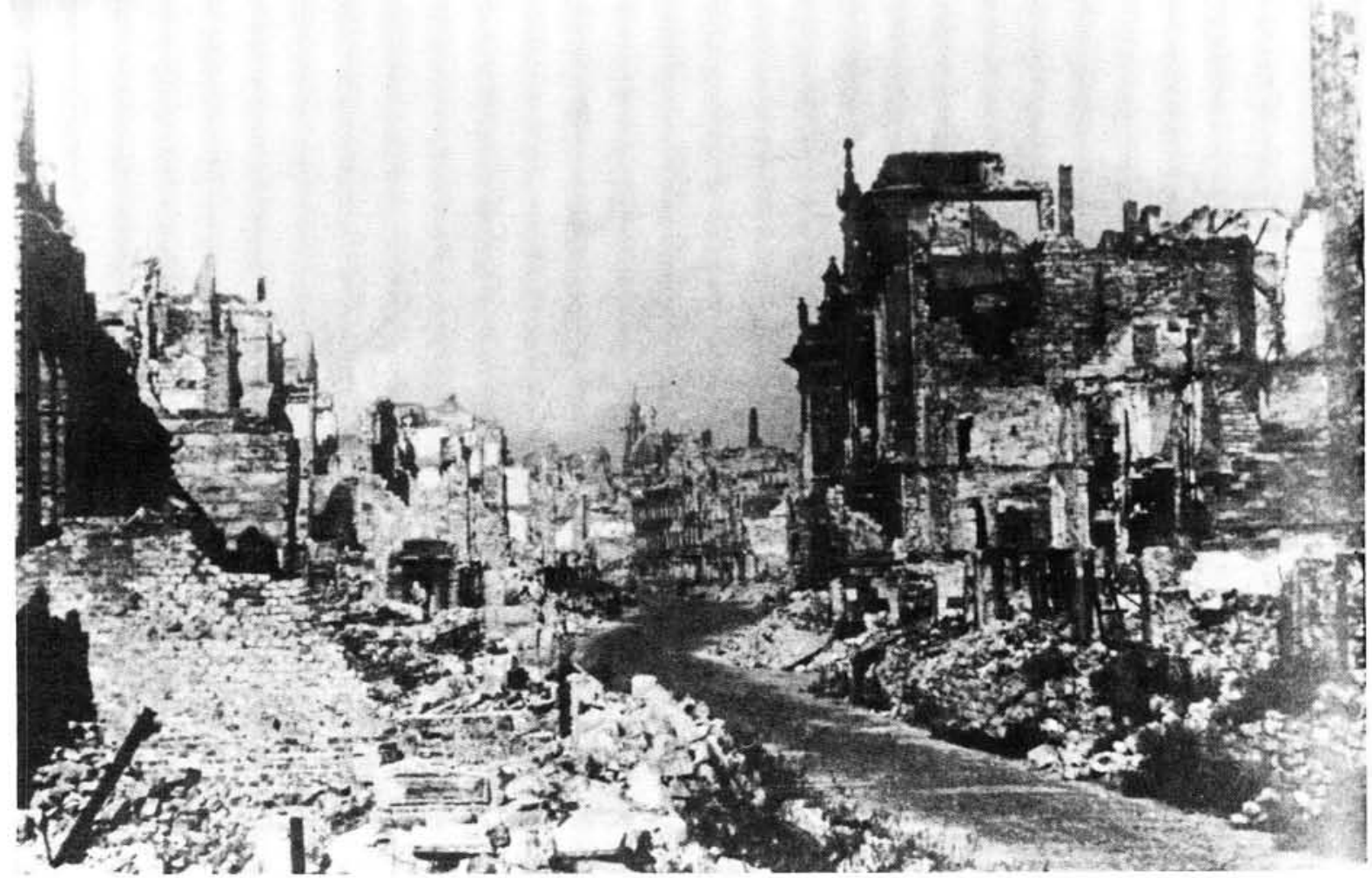


own and the enemy's humanity, to remember what the point of war is and to practice the maxim that war is an instrument of state policy. Soldiers in the field fighting guerilla forces are notorious for committing overkill and atrocities on the civilian population, usually quite contrary to the stated orders and policies of the senior command. However, this seems largely unavoidable if the enemy are merely "culled" or chalked up as "kills"; soldiers need to be impressed upon as to the possible motives of the enemy, his possible misguided ideas as to what he is fighting for. To know the enemy in this way is the first step towards winning a hearts and minds campaign, to understanding his way of thinking and then only with some sense of regret being compelled to fight him with as few ill side-effects as possible to the civilian hostage population.

\section{Passive Resistance and Military Virtue}

Very possible, given the heat of the moment and the all-consuming pressures of battle, even this sort of moral perspective may come to be pushed aside and ignored. Nevertheless, so long as the overall motive of the war being fought is self-defensive and just, as with the Allied Campaign in World War II, such a contingency will be morally better than the pacifist option of capitulation in the face of an enemy with no such moral and ethical scruples. Pacifists would argue here that they do indeed have a positive defensive programme, in the form of Gandhian techniques of passive resistance, successful to a degree against the British in India. It is enough, perhaps, to point out that the colonial British were not the utterly ruthless Nazis or Soviet Communists, that Gandhi's call on Britain to resist the Nazis nonviolently was indescribably ludicrous, and that then as now, mass acceptance and sustained practice of this "turn the other cheek" philosophy is simply not a viable option. While this is not to denigrate the moral basis underlying the theory of non-violent resistance, it does mean that its very impracticality and unworkability under most circumstances may mean an immoral end result since the aggressor would have been granted victory.

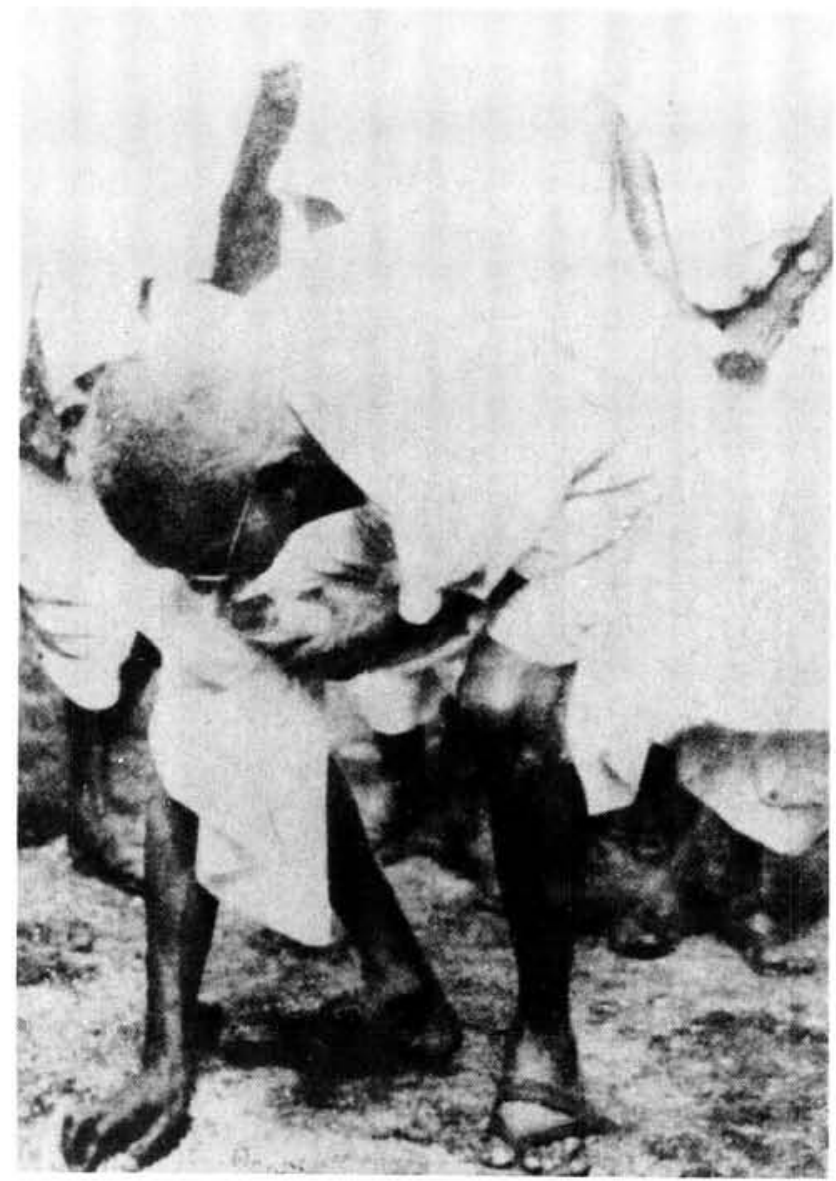

Gandhl gathers up salt from the beach at Dandi during his famous, and ultimately successful, 1930 campaign to break the government's salt monopoly. 
In war, the choice often appears to be between the claims of love and justice, between love of one's enemy despite his sins, and between the need to fight him so that justice might prevail. The Gandhian doctrine has deep affinities with the Gospel of reconciliation, with the ultimate expression of love for one's fellow human being even when one opposes what he stands for. As one proponent puts it "non-violent resistance seeks to persuade the aggressor to recognise in his victim the humanity they have in common, which when recognised fully makes violence impossible. This goal of human recognition is sought through the power of voluntary suffering, by which the victim becomes no longer a victim but instead an active opponent in loving resistance to the man who has refused to recognise him as man. The man of non-violence acts through suffering love to move the unjust opponent to a perception of their common humanity, and thus to the cessation of violence in the commencement of brotherhood. ${ }^{n 7}$

It is as churlish to deny that these sentiments are not simply magnificent as it is downright stupid to believe that there are enough saints in this world to effectively implement them. War is brutally necessary, but as Paskins and Dockrill point out, this is not to overlook the great moral dignity of traditional military values. It is simply not true that men use violence against other human beings only insofar as they neglect the humanity of their enemies. Rommel did not underestimate his opponents' humanity but understood very well the brotherhood of arms: traditionally, soldiers on the battlefield have a deep common bond that is denied to all other man. Indeed, the traditional military code is a difficult and demanding one, requiring moral restraint and self-discipline as great as that of the non-violent. ${ }^{78}$ One has furthermore only to look at the ethically-based Israeli Army doctrine of "purity of arms" to demonstrate that appropriate moral concerns are not necessarily incompatible with even spectacular military prowess.

Overall, then, if it is moral justification that one seeks, a military engaged in the proper conduct of war need concede nothing to the impossibly idealist doctrines of pacifism.

\section{Conclusion}

Enough has been said to warrant the conclusion that pacifism, in all its bewildering complexity, is fundamentally flawed both in terms of its claim to a higher morality and also as a practical policy alternative. In this connection, we have noted its radical and inconsistent nature, its adherence to mistakenly high ideals and its undeserved selfrighteousness. Furthermore, pacifists have allowed themselves to be manipulated by unscrupulous forces who would be the first to overturn the ideals that pacifists claim to be striving for.

On the other hand, the fact remains that for the responsible Christian, for the responsible human being, war is an acute and constant moral problem from which he cannot escape. The sincere witness of the conscientious objector to war can thus have value in reminding us of this fact, and in any case, his principled stand deserves civilised treatment by the civilised state. It has been said, too, that if pacifism is not effective as a cure, it has more justification as a diagnosis of the ultimate irrationality and futility of war. Pacifists point to the fact that when a nation is excessively geared to military ends its social and political ends suffer significantly such that the oft-repeated dictum that war is but 20 percent military and 80 percent political becomes tragically reversed. The unthinking military response can moreover reduce the options for solving a problem, leading to a crucial loss of political flexibility.

The attempt was made to reconcile the claims of morality, so forcefully brought to the fore by pacifism but unfortunately in an extreme form, with a firmly realist approach which is cognisant of the utter necessity for the judicious use of armed force if justice is to prevail. This perspective led to the concept of limited war, that war should be proportionate and limited in ends and means in every way possible, being subject always to responsible political policies. War is thus not to be carried to excess, glamourised or glorified as an end in itself, and every effort must be made to protect the innocent although even this rule cannot be absolute given the contingencies of battle. O'Brien, for instance, notes that "the absolute immunity of non-combatants from intentional direct attack cannot be justified as a moral imperative if the right of legitimate recourse to armed force is conceded." ${ }^{79}$ One thinks here particularly of terrorists who shield themselves among civilian hostages.

Finally, it remains to be said, as Brock points out, that the pursuit of peace in the modern world is too complex an activity to be comprised within the old pacifist slogan "Wars will cease when men refuse to fight. ${ }^{" 80}$ On the other hand, exces- 
sive militarist zeal would hardly contribute to this great goal either. Perhaps the answer is to be found within the words of a Quaker pacifist alert to the fact that pacifists, war resisters and the peace movement would never be serious factors in changing the international system. In the words of Kenneth Boulding:

"Just as war is too important to leave to the generals, so peace is too important to leave to the pacifists. It is not enough to condemn violence, to abstain from it, or to withdraw from it. There must be organisation against it; in other words, institutions of conflict control, or, still other words, government." ${ }^{11}$

Until such a solution is found, the military will always be with us to guard against pacifist illusions and to ensure that civilised values do not ever lack the means for their own defence against tyranny.

* Cpl J.B. Bloom B.A.Hons is a national serviceman attached to the Military Information Bureau of the SADF.

\section{References}

1. Paskins, B. and Dockrill, M., The Ethics of War, Gerald Duckworth and Co., London, 1979, p 112

2. Ibid, p 113 .

3. Brock, P., Twentieth-Century Pacifism, Van Nostrand Reinhold Co., New York, 1970, p v.

4. Ibid, p 2 .

5. Ibid, p 14.

6. Ibid, p 130

7. Ibid, p 159.

8. Ibid, p 177

9. Ibid, pp $40-42$.

10. Ibid, p 16.

11. Ibid, p 45

12. Ibid, p 43 .

13. Ibid, p 159

14. Malament, D., "Selective Conscientious Objection and the Gillette Decision," in Cohen, M., Nagel, T. and Scanion, T. (eds), War and Mora Responsibility, Princeton University Press, New Jersey, 1974, p 180.

15. Brock, op cit, pp 166-167.

16. Ibid, p 160

17. Ibid, pp 171-172.

18. Ibid, pp 173-174.

19. Ibid, pp 174-176.

20. Ibid, pp 187-188.

21. Flynn, G.Q., "Lewis Hershey and the Conscientious Objector: The World War II Experience," Military Affairs, February 1983, p 3

22. Ibid, pp 4-5

23. Brock, op cit, $p 205$

24. Ibid, pp 206-208.

25. Ibid, p 258
26. Malament, op cit, $p 167$.

27. Cited in Brock, op cit, p 96.

28. Holmes, A.F. (ed), War and Christian Ethics, Baker Book house, Michigan, $p 2$.

29. Luther, M., "The Soldier and his Conscience," in Holmes, op cit, p 159

30. Wells, D.A., The War Myth, Pegasus, New York, p 46.

31. Cited in Malament, op cit, pp 170-171.

32. Malament, op cit, $\mathrm{p} 164$

33. Ibid, $p$ 161

34. Paskins and Dockrill, op cit, $\mathrm{p} 121$.

35. Ibid, pp 114-115.

36. Ibid, p 119

37. Brock, op cit, p 179

38. Malament, op cit, $p 167$

39. Narveson, J., "Pacifism: A Philosophical Analysis," in Wasserstrom, R.A. (ed), War and Morality, Wadsworth Publishing Company, Belmont, California, $p 77$.

40. Malament, op cit, $p 182$

41. Griffith, W., "Ban whose Bomb?", Readers Digest, August 1982, p 121

42. Time, April 6, 1981, p 14

43. The Economist, April 2, 1983

44. Chapple, F., "Masters of Manipulation", Readers Digest, August 1982, p 129 .

45. Intelligence Digest World Report, 1 May 1983, p 3.

46. Ibid, $\mathrm{p} 3$

47. Chalfont, A., "The Great Unilateralist Illusion", Encounter, April 1983, p 26.

48. Cited in IDWR, op cit, $p 3$

49. Cited in Chapple, op cit, $p 129$.

50. Chalfont, op cit, pp 18-19.

51. Ibid, p 26.

52. Ibid, p 23

53. Brock, op cit, $p 138$

54. Chalfont, op cit, pp 29-30.

55. Ibid, pp $31-32$.

56. Brock, op cit, p 259

57. Ibid, p 141

58. O'Brien, W.V., War and/or Survival, Doubleday and Company, New York $1969,01$.

59. Narveson, op cit, pp 63-77.

60. Cited in Brock, op cit, pp 148-149.

61. Anscombe, E., "War and Murder", in Wasserstrom, R.A. (ed), War and Morality, Wadsworth Publishing Company, Belmont, California, 1970, pp 42-53.

62. Wasserstrom, R.A., "On the Morality of War" in Wasserstrom, R.A. (ed), op cit, p 94

63. Holmes, op cit, p 4.

64. Bailey, S.D., Prohibitions and Restraints in War, Oxford University Press, London 1972, p 18.

65. Holmes, op cit, $p 4$.

66. Ibid, p 140

67. O'Brien, op cit, pp 62-64.

68. Ibid, pp 108-110.

69. Lewy, G., "Superior Orders, Nuclear Warfare, and the Dictates of Conscience," in Wasserstrom, (ed), op cit, p 133.

70. O'Brien, op cit, p 275.

71. Bailey, op cit, $\mathrm{p} 156$.

72. O'Brien, op cit, p 269.

73. Ibid, pp 269-270

74. See for example Paskins and Dockrill, op cit, pp 1-57.

75. Cited in Wells, op cit, p 134.

76. Paskins and Dockrill, op cit, p 204.

77. Ibid, p 258

78. Ibid, pp $258-259$

79. O'Brien, op cit, $\mathrm{D} x \mathrm{xv}$

80. Brock, op cit, p 260

81. Cited in O'Brien, op cit, $p 98$ 